\title{
Discussion on Professional Construction for Teaching Management Team in Colleges and Universities
}

\author{
Chunfang Wang \\ School of Humanities, Jilin Agricultural University, Changchun 130118, China \\ (E-mail:wangchunfang1975@tom.com)
}

\begin{abstract}
Keywords: Colleges and universities; teaching management team structure; professional development; investigation and research
\end{abstract}

\begin{abstract}
Teaching management team is an important part of the management team of Colleges and universities. The level of teaching management not only restricts the teaching quality of a school, but also affects the development of a school. Correctly facing the present situation of teaching management team structure, paying attention to and strengthening the construction of teaching management team, and promoting professional development of teaching management team, have become the essential method to enhance the competitiveness of Colleges and universities and improve teaching quality. This paper is an empirical study on the professional development of teaching management team in Colleges and universities. Based on the survey results of the current situation of some Colleges and universities, this paper analyzes the current status of teaching management team in Colleges and universities, and draws the conclusion of the practical problems of unreasonable structure and do on existing in the teaching management team in Colleges and universities at present, analyzes the causes of these problems, and tries to provide theoretical and practical support for the professional development of teaching management team structure.
\end{abstract}

\section{Introduction}

In recent years, the development of Colleges and universities is rather rapid, no matter the scale, structure, quality, or efficiency have been greatly improved. The teaching management is the central work of Colleges and universities, and it is the basic guarantee to maintain the normal teaching order, to achieve the goal of talent training, and to improve the quality of teaching. High quality and high level of teaching management requires the construction of a reasonable structure and professional teaching management team. However, the overall quality of the teaching management team in Colleges and universities cannot fully meet the requirements of teaching reform and development, which directly leads to some problems in the construction of teaching management team, directly affecting the improvement of the teaching management level and the efficiency of teaching management. From the current research situation, the structure problem of teaching management team is firstly involved in. To solve this problem, the corresponding countermeasures have been put forward, but still remaining at the theoretical level and practical significance remaining to be considered. Based on these reasons, this paper focuses on the empirical analysis of the current situation investigation of teaching management team in 7 Colleges and universities in an area, profoundly analyzes the current situation and the problems needed to be solved of the teaching management team in Colleges and universities, and puts forward feasible countermeasures, so as to provide theoretical support for the professional construction of College teaching management team. At the same time, it provides feasible suggestions and opinions for the professional development of teaching management team in this area.

\section{Design Questionnaire and Analysis Method}

In order to guarantee the objectivity of the research, in the study of the current situation of the teaching management team in the area, questionnaire is adopted as the research method. The data involved in the study are obtained through the questionnaire, so as to maintain the original character and integrity of the data and get real results in the research process. 
The design and distribution of questionnaire survey and analysis: the questionnaire object is mainly the teaching management staffs of Colleges and universities investigated, a total of 10 topics in the questionnaire, which are all the form of objective choice. It includes the gender, age, work experience, education, professional, professional title, way of being engaged in teaching management of the investigated. In July to September in 2015, the author issued a total of 200 questionnaires, which recovered 174 copies, the recovery rate of $87 \%$; 140 valid questionnaires, the effective rate of $81.7 \%$, in line with the standards and requirements of social survey [1].

Based on the scientific and practical feature of Excel and SPSS analysis method, the questionnaire data statistics analysis uses Excel, data analysis uses SPSS method, and frequency analysis and description analysis in SPSS is adopted in order to get real analysis results, providing convenience for the writing of this paper. What is needed to explain is that the SPSS analysis used in this paper is the basic application analysis, and does not use its complex analysis function, which is also a deficiency of this article.

\section{Analysis on the Present Situation of Teaching Management Team Structure in the Area}

\subsection{Academic Structure}

Education level reflects a person's academic level and the degree of professional technical training. Under normal circumstances, the proportion of those who with higher education in the teaching management team is large, indicating that the quality of this team will be better and the stronger the ability of business.

Table 1 Statistical table of academic structure

\begin{tabular}{llllll}
\hline & Education & Frequency & Percent & $\begin{array}{l}\text { Valid } \\
\text { perception }\end{array}$ & $\begin{array}{l}\text { Accumulati } \\
\text { ve } \\
\text { perception }\end{array}$ \\
\hline $\begin{array}{l}\text { Effective } \\
\text { value }\end{array}$ & $\begin{array}{l}\text { Undergradua } \\
\text { te }\end{array}$ & 71 & 50.7 & 50.7 & 50.7 \\
& $\begin{array}{l}\text { Doctor } \\
\text { Junior }\end{array}$ & 2 & 1.4 & 1.4 & 52.1 \\
& $\begin{array}{l}\text { College } \\
\text { Master }\end{array}$ & 45 & 15.7 & 15.7 & 67.9 \\
& Total & 140 & 32.1 & 32.1 & 100 \\
\hline
\end{tabular}

From the data, College teaching management team in this area still takes a bachelor's degree level staffs as the main force, bachelor's degree level of teaching management personnel accounting for $50.71 \%$ of the investigated, accounting for more than half. Master's degree accounting for $32.14 \%$, accounting for about $1 / 3$, which also shows the tendency that the construction of teaching management team is developing to the high degree of education. However, the proportion of doctoral students accounts for only 32.14\%. Compared with the full-time teachers, doctoral students are very few in the teaching of management positions, and they tend to choose the position of full-time teachers. The undergraduate education level accounts for 15.71\%. According to the survey, most of these people are the managers aged above 45 years who have elder qualifications. On the whole, education level of university teaching management team in this area continues to be improved, but the overall level is still low, and the proportion of staffs with low level is too large in the total, and the proportion of high level in the overall team also needs to be improved. It is supposed to appropriately adjust the proportion of highly educated personnel.

\subsection{Subject Major Structure}

Subject major structure refers to the case of the composing proportion of teaching management personnel in different professionals in the entire teaching management team, which is an important aspect of the analysis of the structure of teaching management team. In general, the larger proportion of the teaching management staffs with relevant professional background in the entire teaching management team, the better the knowledge base of being engaged in this job, and the easier access to the fruits of labor in this job. 
Table 2 Statistical table of subject major structure

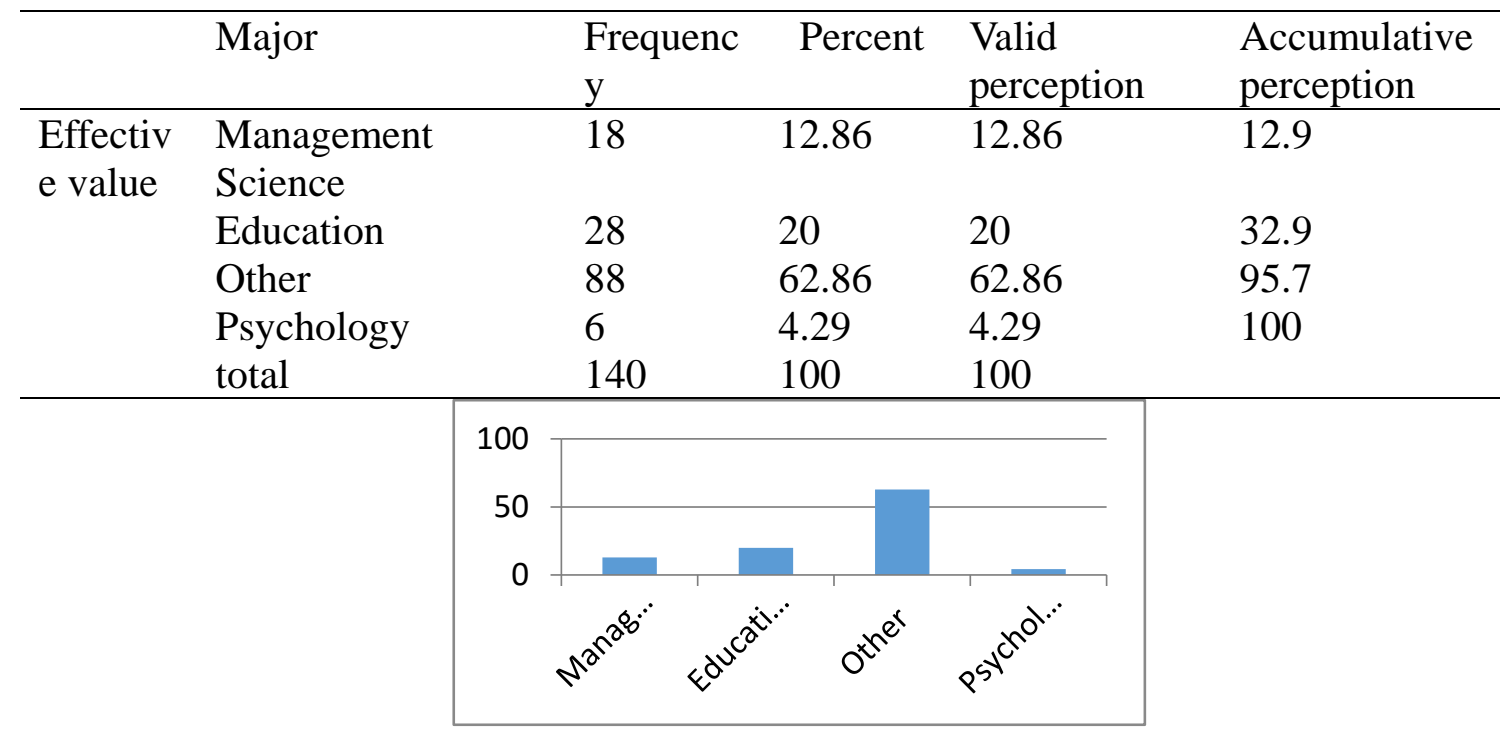

Figure 1 Subject major structure

Teaching management in Colleges and universities is a strong professional work that requires the staffs engaged in teaching management have relevant background knowledge, understand the rules of education, master education and psychology knowledge, and have the corresponding management ability, so as to meet the needs of teaching management work. From the investigation of the structure, staffs with the management, education and psychology education background the university teaching management team in this area is very small, with the management background of only $12.86 \%$, with educational background in education for $20 \%$, with educational background in psychology for $5.7 \%$, and the combined ratio of $25.5 \%$ [2].

\subsection{Tittle Structure}

What the title structure reflects is the total management level and the management work adapt to of a teaching management team.

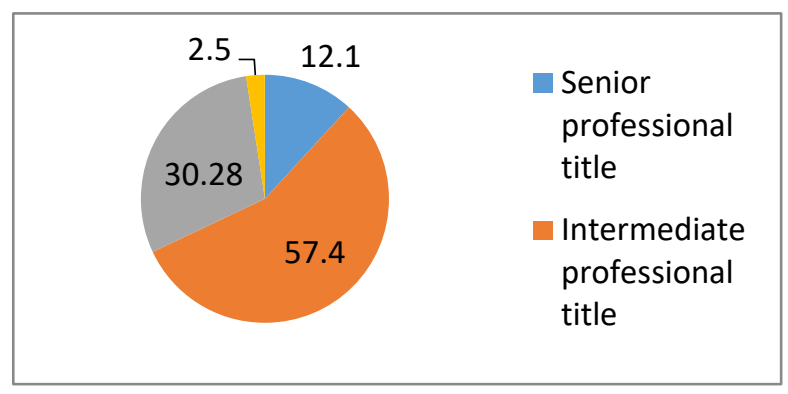

Figure 2 Tittle structure

In this area, the title structure of the teaching management team in Colleges and universities is mainly based on the intermediate professional title, which occupies the highest proportion; the followed is the primary title, and then the senior professional title. Statistics show that intermediate professional title of the teaching management staff in Colleges and universities accounts for $57.4 \%$, with primary or secondary titles accounts for $30.5 \%$, and with senior professional titles accounts for $12.1 \%$ [3]. The results of the data show that there is a great improvement space in the development of teaching management team in Colleges and universities in the area. At the same time, it should reasonably match the staffs with different levels and abilities so that each member can exhibit their capability. 


\section{Analysis on the Problems of the Structure of Teaching Management Team in Colleges and Universities in the Area}

\subsection{Irrational Education Structure}

With the continuous increasing of highly-educated talents, the competition of talents is becoming more and more fierce. At present, the job requirements of all the Colleges and universities on the full-time teachers is becoming higher and higher, so does the requirements on the teaching management staffs. The author thinks that the academic structure of the university teaching management staffs still has the very big adjustment space. According to the survey data, the academic structure of College teaching management staffs in the area is that the proportion of master degree or above teaching management personnel is small, but the number of students below undergraduate education accounts for about $12 \%$. Compared with the current education level of the whole society, it is not reasonable. The normal situation should be highly-educated undergraduate as the main force of teaching management personnel.

\subsection{Unreasonable Subject Major Structure}

As the manager of the school, teaching management personnel must have management, education and other related disciplines as support both in theoretical knowledge and ability. As university administrators, they must accept the study of systematical teaching management knowledge, master a complete teaching management idea, and grasp scientific teaching management methods, but not everyone can do the work of teaching management well. Teaching management work is related to the normal operation of the entire school, the coordinated development of various aspects of the school, and all aspects of teachers and students, which is a highly professional work. While the survey results show that the university teaching management personnel is not scientific in the subject major structure.

\subsection{Disproportionate Title Structure}

The survey data of College teaching management personnel shows that intermediate professional title occupies the highest proportion; the followed is the primary title, and then the senior professional title. Overall, it is reasonable of taking intermediate professional title as the main part, but the senior professional title of the teaching management personnel is too few while the primary title or no title is too much [4]. On the one hand, young members of College teaching management are the majority, because the title assessment is related to the working length. But on the other hand, the staffs with the primary title or no title is too much, is it shown that teaching management staff does not meet the requirements of professional title assessment? Is that the overall quality of the teaching management team not high?

\section{Countermeasures for the Construction of Teaching Management Team Structure in this Area}

\subsection{Attach Importance to Position and Function of Teaching Management Team}

The quality of the teaching management work directly affects the operation and development of Colleges and universities, and has a very important influence on the future of Colleges and universities. To achieve the professional development of teaching management team not only means a breakthrough development to the teaching management team's own construction, but also provides greater security and space for the development of Colleges and universities. Play the role of teaching management team, to create a solid backing for the development of Colleges and universities. The importance of teaching management team of a university is beyond doubt. Teaching management not only needs to run through the overall situation, the various parts of the specific work should also be grasped exactly.

\subsection{Implement Qualification Certificate Authentication System of Teaching Management Personnel}

There are differences in the nature of the work of the full-time teachers and the teaching administrators. The former is mainly based on teaching and educating, and the latter is mainly based on management. Therefore, the author believes that the implementation of professional qualification 
certificate authentication system of the teaching management personnel is very necessary. Similarly, the teaching management personnel qualification authentication system also has its principles and the examination standards. After referring to the principle of teacher qualification authentication system, the author believes that the teaching management personnel qualification authentication system should have the principle of specialization, development, openness, fairness and hierarchy.

\subsection{Standardize Employment Mode}

Face the society to open recruitment, and announce the position applied, the number of candidates, as well as the requirements of the candidates. All the candidates must be eligible for review before participating in the test. The content of the examination includes the academic certificate and teaching management personnel qualification certificate. The application adopts the method of a combination of written examination and interview [5]. Written examination content includes management, educational psychology, teaching management related content and so on. Interview content involves in basic quality that the teaching management staffs should have, including the ability to meet the spot, improvisation, organization and management capabilities, problem-solving skills and so on. Strictly in accordance with the written test results to select the interview staffs, and according to the written examination and interview results to choose the staffs to be employed.

\section{Conclusion}

In the face of fierce competition among Colleges and universities, how to enhance the comprehensive competitiveness of the school, improve the teaching quality, and create their own social image, has become a practical problem urgently needed to be solved. Teaching management team is an important part of the management team in Colleges and universities, and the development of the team directly restricts the teaching quality and the development of the school. Correctly face the present situation of the teaching management team and promote the teaching management team to the professional development have become an important way to enhance the competitiveness of Colleges and universities. While with the increasing emphasis on the quality of teaching, especially the structure and quality of teaching management team become the evaluation indexes of university teaching level. Colleges and universities have to pay more attention to the construction of teaching management team and carry out related policies and measures, providing more support for the professional development of teaching management team in Colleges and universities.

\section{References}

[1] Hayden M, Thompson J. International schools and international education: Improving teaching, management and quality[M]. Routledge, 2013.

[2] LI H, JI G, CUI R, et al. On Xinjiang College Teaching Management Team Construction—-Take Xinjiang Normal University as an example[J]. The Guide of Science \& Education, 2014, 6: 007.

[3] Elias M, Dinah M M, Tome M, et al. The School Management Team Leadership Role in Rural Primary School Setting[J]. Mediterranean Journal of Social Sciences, 2014, 5(7): 367.

[4] Buyl T, Boone C, Hendriks W. Top Management Team Members' Decision Influence and Cooperative Behavior: An Empirical Study in the Information Technology Industry[J]. British Journal of Management, 2014, 25(2): 285-304.

[5] Benoliel P, Somech A. Functional Heterogeneity and Senior Management Team effectiveness: The Mediating Role of School Leadership[J]. Journal of Educational Administration, 2016, 54(4). 